\title{
Odnos ciljeva postignuća, strategija učenja i ocjena u srednjoškolskoj nastavi fizike
}

\author{
Gabrijela Vrdoljak \\ Sveučilište J. J. Strossmayera u Osijeku, Filozofski fakultet u Osijeku, \\ Odsjek za psihologiju, Hrvatska \\ Vesna Vlahović-Štetić \\ Sveučilište u Zagrebu, Filozofski fakultet u Zagrebu, Odsjek za psihologiju, Hrvatska
}

\begin{abstract}
Sažetak
Cilj istraživanja bio je provjeriti odnos ciljeva postignuća, strategija učenja i ocjena u srednjoškolskoj nastavi fizike. Ciljevi postignuća predstavljaju važan motivacijski konstrukt koji je razvijen u okviru teorija samoreguliranog učenja te se dovode u vezu s različitim obrazovnim ishodima kao što su strategije učenja i ocjene. Istraživanje je provedeno na 208 učenika drugog i trećeg razreda općega gimnazijskog usmjerenja. U svrhu ispitivanja ciljeva postignuća i strategija učenja korišteni su Upitnik ciljeva postignuća (Elliot i McGregor, 2001), koji se sastoji od 12 čestica i mjeri četiri cilja postignuća: ovladavanje uključivanjem, ovladavanje izbjegavanjem, izvedbu uključivanjem i izvedbu izbjegavanjem, te Skala strategija učenja (Lončarić, 2014), koja se sastoji od 39 čestica i mjeri tri supskale strategija učenja: ciklus (meta)kognitivne kontrole, dubinsko kognitivno procesiranje i površinsko kognitivno procesiranje. Mjera uspjeha u fizici bila je ocjena na kraju prethodnog razreda. Pretpostavljeni su odnosi među varijablama testirani metodom analize traga unutar strukturalnog modeliranja. Istraživanje je pokazalo da ciljevi postignuća značajno predviđaju obrazovne ishode u nastavi fizike (strategije učenja i ocjene) te da su se pretpostavljeni odnosi, koji se temelje na ranije provedenim istraživanjima, u velikoj mjeri potvrdili. Ciljevi postignuća s tendencijom uključivanja imaju značajan pozitivan efekt na poželjne obrazovne ishode. Ciljevi postignuća s tendencijom izbjegavanja pozitivno su povezane s površinskim procesiranjem. Rezultati su potvrdili i posredujući učinak strategija učenja u odnosu ciljeva postignuća na ovladavanje uključivanjem i ocjena iz fizike. Ovo istraživanje naglašava potrebu za usmjeravanjem učenika na učenje radi stjecanja znanja i kompetencija te potrebu za poticanjem korištenja metakognitivnih strategija. Istraživanje, također, upućuje na moguće nedostatke obrazovnog sustava, kao što je nepostojanje značajnog efekta dubinskoga kognitivnog procesiranja na ocjene iz fizike, što pretpostavlja potrebu i važnost daljnjeg istraživanja u ovom području.
\end{abstract}

Ključne riječi: ciljevi postignuća, strategije učenja, fizika, srednja škola

Gabrijela Vrdoljak, Odsjek za psihologiju Filozofski fakultet Sveučilišta J. J. Strossmayera u Osijeku, Lorenza Jägera 9, 31000 Osijek, Hrvatska. E-pošta: gabrijela.vrdoljak03@gmail.com 


\section{Uvod}

Ciljevi postignuća predstavljaju motivacijski konstrukt razvijen u okviru teorija samoregulacije. Motivacijski konstrukti objašnjavaju smjer ponašanja (izbor) i intenzitet ponašanja (količina truda, ustrajnost). Brojna su istraživanja (Gilman i Anderman, 2006; Gottfried, 1985, 1990; Lin, McKeachie i Kim, 2003; McDermott, Mordell i Stoltzfus, 2001) pokazala da motivacija igra možda najznačajniju ulogu u akademskom postignuću. Smatra se da akademska motivacija opada od djetinjstva prema adolescenciji što pridonosi povećanoj brizi zbog nedostatka ili nepostojanja akademske motivacije među adolescentima (McGeown i sur., 2014). Ciljevi postignuća često se definiraju kao svrha ponašanja u situaciji učenja (Ames, 1992). Cilj vezan za postignuće je kognitivna reprezentacija usmjerena na buduće događaje - ona regulira ponašanje prema ishodu vezanom za kompetentnost koji pojedinac nastoji ostvariti ili izbjeći (Hulleman, Schrager, Bodmann i Harackiewicz, 2010). Stoga, različita se ciljna usmjerenja dovode u vezu s različitim obrazovnim ishodima. Tradicionalna je podjela ciljeva postignuća usmjerenost na ovladavanje (zadatak, vještinu ili učenje) i usmjerenost na izvedbu (Elliot, 1997; prema Elliot i McGregor, 2001). Učenicima usmjerenim na ovladavanje glavni je cilj postizanje kompetencija $\mathrm{u}$ onome što se uči, dok je učenicima usmjerenim na izvedbu fokus u demonstriranju kompetencija u usporedbi s drugima.

Noviji modeli ciljeva postignuća razlikuju tri (trihotomni model) ili četiri različita cilja (model 2x2). Krajem devedesetih godina prošlog stoljeća Elliot i suradnici ponudili su trihotomni model u kojem se cilj izvedbe dijeli na izvedbu uključivanjem i izvedbu izbjegavanjem (Elliot i Church, 1997). U sljedećem koraku Elliot i McGregor (2001) predlažu još jednu promjenu u teoriji, a to je razdvajanje cilja ovladavanja na cilj ovladavanja uključivanjem i cilj ovladavanja izbjegavanjem, čime su formirali model ciljeva postignuća $2 \times 2$.

U ovom modelu postoje dvije dimenzije ciljeva postignuća - definicija i valencija. Definicija predstavlja standard prema kojem učenik procjenjuje svoje postignuće u odnosu na uspjeh drugih (ciljevi izvedbe) ili u odnosu na vlastito napredovanje (ciljevi ovladavanja). Valencija se definira u terminima pozitivne, željene mogućnosti (uspjeh) i negativne, neželjene mogućnosti (neuspjeh). Ona ima dvije opcije: jedna je poželjna vjerojatnost ishoda (uspjeh), a druga je nepoželjna (neuspjeh). Dakle, ovaj model pretpostavlja postojanje četiriju ciljeva postignuća: ovladavanje uključivanjem, ovladavanje izbjegavanjem, izvedbu uključivanjem i izvedbu izbjegavanjem. Učenici usmjereni na ovladavanje uključivanjem nastoje ovladati gradivom i steći kompetencije dok su učenici usmjereni na ovladavanje izbjegavanjem usmjereni na izbjegavanje neuspjeha u učenju i razumijevanju materijala te sprječavanje neuspješnih postignuća u odnosu na vlastite ranije učinke. Payne, Youngcourt i Beaubien (2007) proveli su metaanalizu u okviru literature koja se bavila ciljevima postignuća te ispitali ulogu mogućih prediktora i posljedica ciljeva postignuća. Analizom radova autori su utvrdili da su istraživanja uključivala 
slijedeće prediktore: osobine ličnosti, kognitivne sposobnosti, implicitne teorije inteligencije, potrebu za postignućem, samopoštovanje i samoefikasnost. Posljedice ciljeva postignuća podijeljene su na neposredne i posredne. U skupinu neposrednih posljedica svrstane su sljedeće varijable: postavljanje ciljeva (visoki i niski), strategije učenja, traženje povratne informacije i situacijska anksioznost, a pod posredne: učenje, akademska uspješnost, izvedba na zadatku i uspješnost u poslu. Značajan su učinak na ciljeve postignuća imale: osobine ličnosti, potreba za postignućem i samoefikasnost. Veza između ciljeva postignuća i implicitnih teorija inteligencije pokazala se značajnom, ali vrlo slabom, dok se veza između ciljeva postignuća i kognitivnih sposobnosti nije pokazala značajnom. Iako su ciljevi postignuća značajno predviđali i neposredne i posredne posljedice, metaanaliza Paynea i suradnika (2007) pokazala je da su ciljevi postignuća bolji prediktor neposrednih nego posrednih posljedica. Uz ciljeve postignuća s tendencijom uključivanja obično se vežu pozitivni obrazovni ishodi (interes, samoefikasnost, dubinske strategije učenja), s tim da istraživanja pokazuju da najviše dobrobiti za učenje proizlazi iz usmjerenosti na ovladavanje uključivanjem (Senko, Durik i Harakiewicz, 2008). Istraživanja su pokazala pozitivnu povezanost između usmjerenosti na ovladavanje i različitih obrazovnih ishoda: samoefikasnosti (Diseth, 2011), interesa (Harakiewicz, Barron, Tauer, Carter i Elliot, 2000), strategija učenja "višeg" reda (Radosevich, Vaidyanathan, Yeo i Radosevich, 2004) i samoreguliranog učenja (Pintrich i De Groot, 1990). U nekim je istraživanjima (npr. Fenollar, Roman i Cuestas, 2007; Payne i sur., 2007; Rončević Zubković i KolićVehovac, 2014) dobivena pozitivna povezanost ciljeva ovladavanja sa školskim/akademskim uspjehom. Ipak, kada se u obzir uzmu isključivo rezultati na testu ili ocjene, najveća korist proizlazi iz usmjerenosti na izvedbu s tendencijom uključivanja (Senko i sur., 2008). Neka istraživanja dovode usmjerenost na izvedbu u vezu s negativnim obrazovnim ishodima kao što su površinske strategije učenja (Ames, 1992), u drugima ta veza nije potvrđena, a u nekim je istraživanjima dobivena pozitivna veza između usmjerenosti na izvedbu uključivanjem i pozitivnih obrazovnih ishoda kao što su samoefikasnost, efektivne strategija učenja i ocjene (Elliot, 1999; prema Kaplan i Maehr, 2007). Unatoč tome što neka istraživanja sugeriraju pozitivan učinak usmjerenosti na izvedbu uključivanjem i pozitivnih obrazovnih ishoda, metaanaliza koja se bavila usporedbom efekata eksperimentalno izazvanih ciljeva postignuća na obrazovne ishode upućuje na znatno izraženije dobrobiti poticanja usmjerenosti na ovladavanje (Utman, 1997). Ciljevi postignuća s tendencijom izbjegavanja najčešće se vežu uz negativne obrazovne ishode (strah, anksioznost, nisku samoefikasnost, površinske strategije učenja, loše ocjene), a to osobito vrijedi za ciljeve postignuća na izvedbu izbjegavanjem (Senko i sur., 2008).

Strategije učenja (Oxford, 1990; prema Sorić, 2014) definiraju se kao operacije koje učenik upotrebljava da si olakša stjecanje, pohranu ili dosjećanje informacija, odnosno kao specifične akcije koje učenik poduzima kako bi učenje učinio lakšim, bržim, zabavnijim, učinkovitijim, kontrolabilnijim i transferabilnijim. Najčešće se dijele na kognitivne (ponavljanje, organizaciju, elaboraciju) i metakognitivne 
(planiranje, praćenje, evaluacije) ili na strategije dubinskog i površinskog procesiranja (Lončarić, 2014). U strategije dubinskog procesiranja ubrajaju se strategije "višeg reda", kao što su organizacija i elaboracija, dok se u strategije površinskog procesiranja ubrajaju strategije učenja napamet, bez puno promišljanja o gradivu koje se uči. Lončarić (2014) dijeli strategije učenja: na ciklus (meta)kognitivne kontrole učenja (ponavljanje i uvježbavanje, kontrola tijeka i ishoda učenja), duboko kognitivno procesiranje (elaboracija, organizacija, primjena, kritičko mišljenje) i površinsko kognitivno procesiranje (memoriranje, usmjerenost na minimalne zahtjeve). Dubinski pristup učenju dovodi do razumijevanja sadržaja i strukturalno kompleksnih ishoda koji su afektivno zadovoljavajući (npr. uživanje u učenju, interes) dok površinski pristup rezultira pamćenjem i ponavljanjem činjenica te ne dovodi do razumijevanja prave prirode informacija (Biggs, 1985; Coutinho i Neuman, 2008). Metakognitivni procesi su važni jer dovode do konceptualnih promjena u učenju što omogućuje duže zadržavanje materijala i primjenu na nov način (Georghiades, 2000). Kipins i Hofstein (2007) navode da važnost poticanja metakognitivnih vještina leži u sljedećim spoznajama: 1 . Metakognitivni procesi promiču učenje $\mathrm{s}$ razumijevanjem. Učenje $\mathrm{s}$ razumijevanjem podrazumijeva mogućnost da se stečeno znanje primijeni u novom kontekstu, odnosno primjeni u svakodnevnom životu. 2. Stalnim unaprjeđenjem tehnologije postojeća znanja nisu dovoljna, već je potrebno učenje novih znanja koja će biti ključna u budućnosti. 3 . Metakognitivne vještine omogućuju samostalno učenje, koje zahtjeva svijest o vlastitom znanju i kako to znanje proširiti. Gunstone (1991; prema Georghiades, 2000) navodi da učenici često ne znaju svrhu onoga što se uči na nastavi. Metakognitivni procesi podrazumijevaju svijest o onome što se uči, praćenje i kontrolu procesa učenja. Za razvoj su znanstvenog mišljenja (kao npr. u nastavi fizike) ti procesi važni jer je bitno ne samo da osoba promijeni mišljenje u skladu s dokazima već da razumije zašto je promijenila mišljenje. Strategije dubinskog procesiranja te metakognitivne strategije trebale bi omogućiti bolje razumijevanje materijala, a time i veći uspjeh na testovima, odnosno bolju ocjenu. Istraživanja koja su se bavila odnosom ciljeva postignuća i strategija učenja pokazuju da su strategije učenja neposredne posljedice ciljeva postignuća, dok su rezultati na testu i ocjene posredne posljedice ciljeva postignuća (Payne i sur., 2007). Dakle, ciljevi postignuća trebali bi imati indirektan učinak na ocjene preko strategija učenja. Metaanaliza Paynea i suradnika (2007) utvrdila je značajnu pozitivnu povezanost između usmjerenosti na ovladavanje i strategija učenja. Istraživanje Disetha (2011) pokazalo je pozitivnu povezanost između usmjerenosti na ovladavanje i dubinskih strategija učenja, a negativnu vezu između usmjerenosti na ovladavanje i površinskih strategija učenja. $U$ istom je istraživanju dobivena pozitivna veza između izvedbe uključivanjem i dubinskih strategija učenja, te izvedbe izbjegavanjem i površinskih strategija učenja. Istraživanje provedeno na studentima fizike pokazalo je potpunu medijaciju metakognicije u odnosu između usmjerenosti na ovladavanje i akademskog uspjeha (Mirzaei, Phang, Sulaiman, Kashefi i Ismail, 2012). Istraživanje Barzegara (2012) na modelu 2x2 upućuje na pozitivnu povezanost 
između ciljeva postignuća s tendencijom uključivanja i dubinskih strategija učenja, te negativnu povezanost između ciljeva postignuća $s$ tendencijom uključivanja $i$ površinskih strategija učenja. Elliot i McGregor (2001) te Moller i Elliot (2006) potvrdili su pozitivnu povezanost ovladavanja uključivanjem $\mathrm{s}$ dubinskim procesiranjem, te izvedbe izbjegavanjem s površinskim procesiranjem materijala. Većina je istraživanja provedena na dihotomnom i trihotomnom modelu ciljeva postignuća što upućuje na potrebu za daljnjim ispitivanjem odnosa ciljeva postignuća (koje se temelje na modelu 2x2) i obrazovnih ishoda.

Ciljevi postignuća ispitivali su se u općem školskom/akademskom kontekstu (npr. Finney, Pieper i Barron, 2004; Jakšić i Vizek Vidović, 2008; Rončević Zubković i Kolić-Vehovec, 2014) ili u kontekstu specifičnog predmeta/kolegija (npr. Mirzaei i sur., 2012; Rovan, Pavlin-Bernardić i Vlahović-Štetić, 2013). Metaanaliza Paynea i suradnika (2007) pokazala je da se uspjeh u zadacima i učenju može bolje predvidjeti na temelju ciljeva postignuća vezanih uz specifično područje ili situaciju nego na temelju općih postignuća. Cilj je ovog istraživanja bio ispitati odnos ciljeva postignuća, strategija učenja i ocjena iz fizike. Ove su varijable ispitane kontekstu nastave fizike s obzirom da fiziku učenici često procjenjuju teškom i nezanimljivom (Marušić, 2006) te da kompleksnost sadržaja fizike zahtjeva dubinsko procesiranje materijala, planiranje, praćenje i evaluaciju procesa učenja. Istraživanja pokazuju da korištenje isključivo učenja napamet generira pogrešno zaključivanje i razumijevanje znanstvenih koncepata (BouJaoude, 199; prema Cavallo, Rozman, Blickenstaff i Walker, 2003). Jedna je studija pokazala da je dubinsko procesiranje povezano $\mathrm{s}$ razumijevanjem sadržaja dok je učenje napamet povezano $\mathrm{s}$ većim brojem pogrešnih zaključaka o Newtnovoj fizici (Williams i Cavallo, 1995; prema Cavallo i sur., 2003). Dakle, možemo zaključiti da je za razumijevanje koncepata pri učenju fizike ključan odabir adekvatnih strategija učenja. S obzirom na to da se strategije učenja svrstavaju u posljedice ciljeva postignuća (Payne i sur., 2007), istraživanje učeničkih ciljeva postignuća u kontekstu nastave fizike trebalo bi dati neke odgovore o mogućnostima predviđanja uspjeha u fizici.

S obzirom na nalaze dosadašnjih istraživanja postavljen je model koji predviđa:

H1: Pozitivan efekt ciljeva postignuća $\mathrm{s}$ tendencijom uključivanja na metakognitivnu kontrolu, dubinsko procesiranje i ocjene, a negativan efekt na površinsko procesiranje.

H2: Negativan efekt ciljeva postignuća $\mathrm{s}$ tendencijom izbjegavanja na metakognitivnu kontrolu, dubinsko procesiranje i ocjene, a pozitivan efekt na površinsko procesiranje.

H3: Pozitivan efekt metakognitivne kontrole i dubinskog procesiranja na ocjene, a negativan efekt površinskog procesiranja na ocjene.

H4: Posredujuću ulogu strategija učenja u odnosu ciljeva postignuća i ocjena. 


\section{Metoda}

\section{Sudionici}

U istraživanju je sudjelovalo 208 učenika drugog $(N=111)$ i trećeg $(N=97)$ razreda općega gimnazijskog usmjerenja (151 ženskog i 57 muškog spola). Dob učenika kretala se od 15 do 18 godina $(M=16.47, S D=0.56)$.

\section{Instrumenti}

Upitnik ciljeva postignuća (Elliot i McGregor, 2001) sastoji se od četiri supskale (četiri cilja postignuća): ovladavanje uključivanjem (primjer čestice: Želja mi je u potpunosti svladati gradivo fizike.), ovladavanje izbjegavanjem (primjer čestice: Brinem se da na fizici možda neću naučiti sve što bih mogao/la.), izvedba uključivanjem (primjer čestice: Važno mi je da na fizici budem bolji/a od drugih učenika.) i izvedba izbjegavanjem (primjer čestice: Samo želim izbjeći slabe rezultate na fizici.). Pouzdanost pojedinačnih skala (Cronbach $\alpha$ ) iznosi .86 za ovladavanje i izvedbu uključivanjem, .81 za ovladavanje izbjegavanjem te .59 za izvedbu izbjegavanjem. Ispitanici procjenjuju na skali od 1 do 7 u kojoj se mjeri određena tvrdnja odnosi na njih, pri čemu 1 - uopće se ne odnosi na mene, a 7 - u potpunosti se odnosi na mene. Čestice su prilagođene kako bi se učenici usmjerili na ponašanja na nastavi fizike.

Skala strategija učenja (Lončarić, 2014) sastoji se od tri supskale: ciklusa (meta)kognitivne kontrole učenja, dubokoga kognitivnog procesiranje i površinskoga kognitivnog procesiranje. Ciklus (meta)kognitivne kontrole uključuje ponavljanje i uvježbavanje te kontrolu tijeka i ishoda učenja. Ponavljanje i uvježbavanje odnosi se na usmjeravanje pozornosti na informaciju i njezino zadržavanje u aktivnom radnom pamćenju (primjer čestice: Kada učim fiziku, najčešće se pripremam tako da više puta pročitam gradivo ili uvježbam mnoge zadatke koje moram riješiti.), koje se konceptualno razlikuje od memoriranja u okviru supskale površinsko kognitivno procesiranje. Kontrola tijeka i ishoda učenja uključuje: praćenje pažnje, samotestiranje radi provjere razumijevanja učenog materijala, nadgledanje shvaćanja i rješavanja testa kao pripreme za ispit (primjer čestice: Za vrijeme učenja fizike često sam/a sebi postavljam pitanja da bih bio/la siguran/a jesam li sve dobro razumio/jela.). Duboko kognitivno obuhvaća: elaboraciju, organizaciju, primjenu i kritičko mišljenje (primjer čestice: Pokušavam povezati informacije koje učim iz fizike s gradivom iz različitih predmeta $i$ informacijama koje sam dobio/la izvan škole). Površinsko kognitivno procesiranje uključuje memoriranje i usmjerenost na minimalne zahtjeve (primjer čestice: Gradivo fizike uglavnom učim doslovno i napamet.). Pouzdanost skale (Cronbach $\alpha$ ) iznosi .89 za ciklus (meta)kognitivne kontrole i duboko kognitivno procesiranje, a .84 za površinsko kognitivno procesiranje. Ispitanici na skali od pet stupnjeva procjenjuju u kojoj se mjeri koriste strategijama učenja navedenim u pojedinim 
tvrdnjama (od 1 - tako nisam nikada radio/la do 5 - uvijek tako radim). Čestice su prilagođene kako bi se učenici usmjerili na ponašanja na nastavi fizike.

\section{Postupak}

Istraživanje je provedeno na nastavi fizike na učenicima drugog i trećeg razreda gimnazije, općeg usmjerenja. Učenici su bili zamoljeni da sudjeluju u istraživanju te im je rečeno da je sudjelovanje dobrovoljno. Također, bili su zamoljeni da odgovaraju iskreno jer će individualni rezultati i rezultati njihova razreda biti dostupni samo glavnom istraživaču, a javnosti će biti dostupni samo ukupni rezultati na razini cijele grupe (od 208 sudionika). Napomenuto je da će po završetku istraživanja biti obaviješteni o ključnim rezultatima. Od učenika su prvo prikupljeni podatci o dobi i spolu te ocjeni iz fizike na kraju prethodnog razreda, zatim su ispunjavali Upitnik ciljeva postignuća te Upitnik strategija učenja.

Pri obradi su rezultata, u svrhu testiranja postavljenih hipoteza, korišteni statistički programi SPSS 19 i AMOS 18.

\section{Rezultati}

Prvo su prikazani deskriptivni pokazatelji ispitanih varijabli te interkorelacije (Tablica 1.).

Mjera veličine povezanosti izražena je Pearsonovim koeficijentom korelacije. Rezultati pokazuju najjaču pozitivnu povezanost između ovladavanja uključivanjem i poželjnih strategija učenja (metakognitivna kontrola i dubinsko procesiranje), te najjaču negativnu povezanost između ovladavanja uključivanjem i površinskog procesiranja. Sličan trend pokazuje odnos između izvedbe uključivanjem i strategija učenja, međutim, korelacije su u ovom slučaju nešto niže. Ipak, kada se uzmu u obzir ocjene, tada je najveća povezanost izvedbe uključivanjem i ocjena. Ciljevi postignuća $\mathrm{s}$ tendencijom izbjegavanja dosta su nisko povezani sa strategijama učenja, dok povezanost ovih ciljeva postignuća s ocjenama nije značajna ni na razini od 5\% rizika. Kad je riječ o korelacijama među ciljevima postignuća, one se kreću od neznačajne (.12) do .42, što odgovara i dobivenim korelacijama u istraživanju Elliota i McGregora (2001), koji su dobili korelacije od neznačajne (-.05) do .40.

Kako bismo odgovorili na problem istraživanja, tj. provjerili odnos ciljeva postignuća, strategija učenja te ocjena iz fizike korištena je analiza traga unutar strukturalnog modeliranja. Analiza traga omogućava istraživaču simultanu provjeru kompleksnih veza (direktnih i indirektnih) unutar nekog skupa varijabli. Ova je analiza metodološki alat koji omogućava, na temelju kvantitativnih korelacijskih podataka, otkrivanje procesa u podlozi određenog ishoda (Lleras, 2005). U svrhu procjene stupnja podudarnosti pretpostavljenog modela $\mathrm{s}$ podacima korišteni su sljedeći pokazatelji: Hi kvadrat test, CFI (Comparative fit index), NFI (Normed-fit 


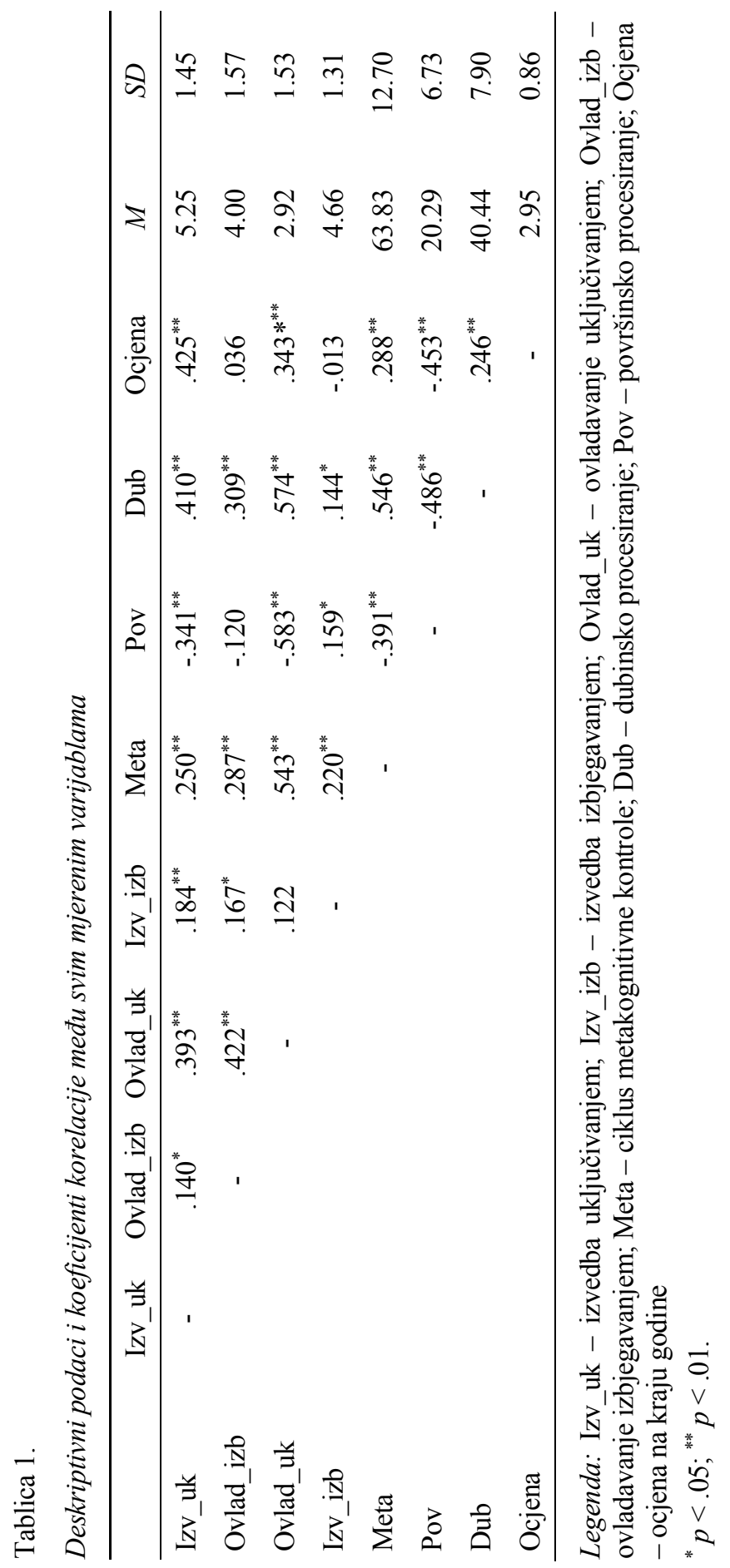


index), GFI (Goodness-of-fit statistic), SRMR (Standardised root means quare residual) te RMSEA (Root mean square error of approximation). Dobivene vrijednosti pokazuju zadovoljavajuću pouzdanost modela $\left(\chi^{2}=6.62, d f=2, N=208\right.$, $p=.04, \mathrm{CFI}=0.99, \mathrm{NFI}=0.99, \mathrm{GFI}=0.99, \mathrm{SRMR}=0.05, \mathrm{RMSEA}=0.075) . \mathrm{Iz}$ prikaza odnosa ciljeva postignuća, strategija učenja i ocjena iz fizike (Slika 1.) možemo uočiti da najveći efekt na strategije učenja ima cilj postignuća usmjerenosti na ovladavanje uključivanjem $(\beta$ (meta $)=.50, p<.01, \beta$ (dubinsko $)=.45, p<.01$, $\beta$ (površinsko) $=-.58, p<.01)$, međutim, ovaj cilj postignuća nema izravan efekt na ocjene. Usmjerenost na izvedbu uključivanjem ima značajan efekt na strategije dubinskog i površinskog procesiranja $(\beta($ dubinsko $)=.22, p<.01, \beta($ površinsko $)=-$ $.17, p<.01$ ), iako je taj efekt nešto slabiji nego efekt usmjerenosti na ovladavanje uključivanjem, te značajan direktan efekt na ocjene $(\beta=.32, p<.01)$. Ciljevi postignuća $\mathrm{s}$ tendencijom izbjegavanja pozitivno su povezani $\mathrm{s}$ površinskim procesiranjem $\mathrm{s}$ tim da jači efekt na površinsko procesiranje ima usmjerenost na izvedbu $[\beta=.24, p<.01 \mathrm{u}$ odnosu na ovladavanje $(\beta=.11, p=.05)]$. Važnost posredujuće uloge strategija učenja u odnosu ciljeva postignuća i ocjena iz fizike provjerena je metodom aproksimacije Monte Carlo. Baron i Kenny (1986) navode tri kriterija koja moraju biti zadovoljena da bi se moglo govoriti o posredujućem efektu: mora postojati značajna povezanost (1) prediktora i kriterija te (2) prediktora i medijatora te, također, (3) medijator mora biti značajan prediktor ishoda u jednadžbi koja uključuje oboje, i medijator i prediktor. U slučaju kada, uz kontrolu medijatora, prediktor nema značajan efekt na kriterij, tada govorimo o potpunoj medijaciji (kao što je to u ovom slučaju). Rezultati su potvrdili posredujući učinak strategija učenja (metakognitivne kontrole i površinskog procesiranja) u odnosu ciljeva postignuća na ovladavanja uključivanjem i ocjena iz fizike $(\beta=.20, p<.01)$, odnosno pokazali su kako usmjerenost na ovladavanje uključivanjem kod učenika upravo indirektno, putem strategija učenja doprinosi objašnjenju ocjene iz fizike.

Na Slici 1. (koja prikazuje testirani model) punom su linijom prikazani pretpostavljeni i značajni odnosi, dok su pretpostavljeni odnosi koji se nisu pokazali značajnim, prikazani isprekidanom linijom. Na Slici 1 nisu prikazane (zbog bolje preglednosti) korelacije među ciljevima postignuća te korelacije među strategijama učenja. Korelacija između dva cilja s tendencijom izbjegavanja (na ovladavanje i na izvedbu) nije značajna i iznosi $r=.11$, dok je korelacija između ciljeva postignuća usmjerenosti na izvedbu (putem uključivanja i izbjegavanja) na granici značajnosti i iznosi $r=.13, p<.05$. Korelacija između ciljeva ovladavanja (putem uključivanja i izbjegavanja) iznosi $r=.38, p<.01$, a korelacija među ciljevima s tendencijom uključivanja (na ovladavanje i na izvedbu) iznosi $r=.34, p<.01$. Korelacije među strategijama učenja su značajne uz rizik od $1 \%$ i iznose $r$ (meta i dubinsko) $=.33, r$ $($ dubinsko i površinsko $)=-.24$ i $r$ (meta i površinsko $)=-.18$. Na Slici 1. istaknute su vrijednosti iznad medijatora i ishodne varijable koje prikazuju proporciju objašnjene varijance. Dakle, ciljevi postignuća ukupno objašnjavaju 30\% ciklusa metakognitivne kontrole, $35 \%$ dubinskog procesiranja i $44 \%$ površinskog 
procesiranja. Ciljevi postignuća i strategije učenja zajedno ukupno objašnjavaju $31 \%$ varijance ocjena iz fizike.

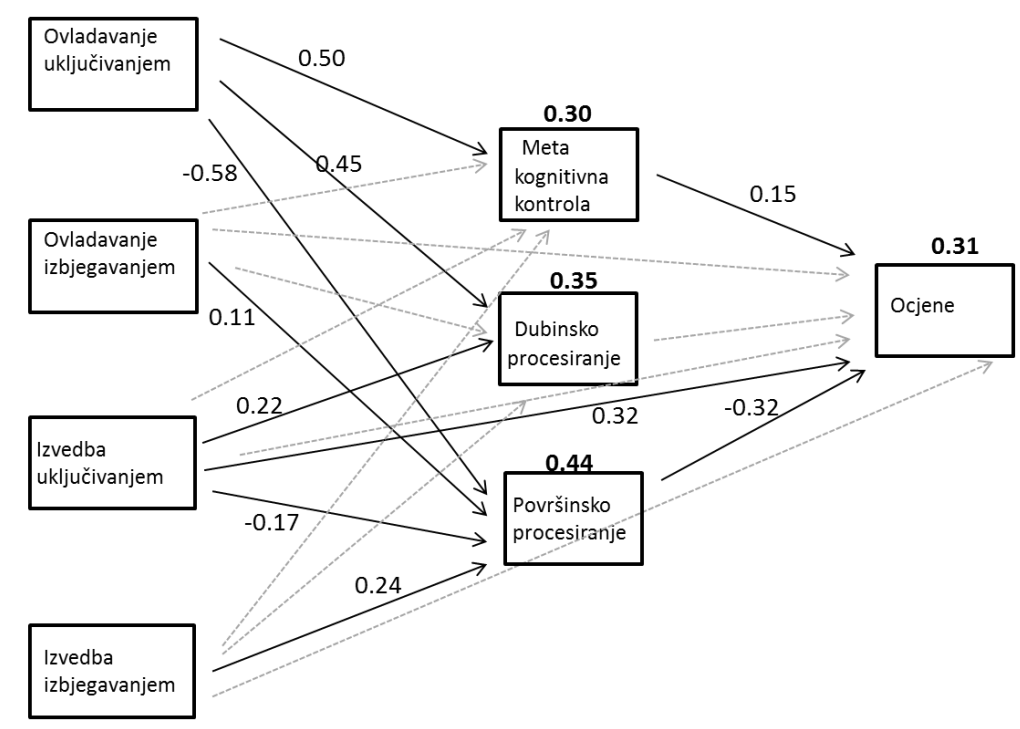

Slika 1. Prikaz odnosa ciljeva postignuća, strategija učenja i ocjena iz fizike.

\section{Rasprava}

Možemo zaključiti da je potvrđena većina pretpostavljenih odnosa. Dobiveni su rezultati u skladu s literaturom (Elliot i McGregor, 2001; Moller i Elliot, 2006; Senko i sur., 2008). Ciljevi postignuća s tendencijom uključivanja imaju značajan pozitivan efekt na poželjne obrazovne ishode, s napomenom da je jači efekt ovladavanja uključivanjem na strategije učenja (korištenje više poželjnih strategija učenja, a manje nepoželjnih), a na ocjene jedini značajan izravan učinak ima usmjerenost na izvedbu uključivanjem. Iako nam matrica korelacija govori da su ciljevi ovladavanja uključivanjem i ciljevi izvedbe uključivanjem u vrlo sličnom odnosu sa strategijama učenja i ocjenama, testirani model (kada uključimo sve varijable) govori da će učenje s razumijevanjem i željom za savladavanjem gradiva imati najviše efekta na korištenje poželjnih strategija učenja dok će usmjerenost na uspoređivanje drugima i težnja za biti bolji od drugih najveći učinak imati na ocjene iz fizike. Ciljevi postignuća $\mathrm{s}$ tendencijom izbjegavanja povezani su s negativnim obrazovnim ishodima (učenjem napamet i zadovoljavanjem minimalnih zahtjeva), što je također u skladu s prethodnim istraživanjima (Barzegar, 2012; Elliot i McGregor, 2001; Moller i Elliot, 2006). Izvedba izbjegavanjem snažniji je prediktor površinskog procesiranja (Slika 1.), što je također u skladu s literaturom (Senko i sur., 2008), gdje se navodi da je s negativnim ishodima najviše povezana izvedba izbjegavanjem. 
Dakle, učenici kojima je cilj izbjegavanje neuspjeha u odnosu na druge učenike, tj. samo da ne budu lošiji od drugih, skloniji su površinskom procesiranju materijala. Ciklus metakognitivne kontrole pozitivan je prediktor ocjena iz fizike, učenici koji ponavljaju i uvježbavaju gradivo te prate tijek i ishod učenja imaju i bolje ocjene iz fizike. Ovakav je odnos između ciklusa metakognitivne kontrole i ocjena u nastavi fizike očekivan jer, kako navodi Georghiades (2000), metakognitivni procesi dovode do konceptualnih promjena u učenju što omogućuje duže zadržavanje materijala i primjenu na nov način. Za razvoj znanstvenog mišljenja (kao npr. u nastavi fizike) ti su procesi važni jer je bitno ne samo da osoba promijeni mišljenje u skladu $\mathrm{s}$ dokazima već da razumije zašto je promijenila mišljenje. Istraživanje Mirzaei i sur. (2012) provedeno na studentima fizike također dovodi u vezu metakognitivne procese $\mathrm{i}$ uspjeh. Površinsko je procesiranje negativan prediktor ocjena, učenici koji uče napamet i bez razumijevanja postižu lošiji uspjeh u fizici. Ovakav je rezultat također u skladu s literaturom (Lončarić, 2014; Marton i Saljo, 1976), u kojoj se navodi da će površinske strategije učenja najvjerojatnije dovesti do niže kvalitete svih ishoda učenja. Dubinsko se procesiranje nije pokazalo značajnim prediktorom ocjena. Iako ovakav rezultat nije očekivan, neka su druga istraživanja također pokazala neznačajnost dubinskog procesiranja u predviđanju školskog/akademskog uspjeha (npr. Diseth i Martinsen, 2003; Vrdoljak, Kristek, Jakopec i Zarevski, 2014). Indirektan je efekt ciljeva postignuća usmjerenosti na ovladavanje uključivanjem na ocjene strategijama učenja također očekivan jer učenici koji uče s razumijevanjem u većoj mjeri ponavljaju i uvježbavaju gradivo te prate tijek i ishod učenja (metakognitivna kontrola), a manje su usmjereni na zadovoljavanje minimalnih uvjeta te manje uče napamet (površinsko procesiranje), što će u konačnici pridonijeti i boljem uspjehu (ocjeni). Posredujuća uloga metakognicije između ciljeva postignuća usmjerenosti na ovladavanje i uspjeha dobivena je i u istraživanju Mirzaei i sur. (2012).

Postavlja se pitanje: Zašto je izvedba uključivanjem bolji prediktor ocjena od ovladavanja uključivanjem te zašto dubinsko procesiranje ne predviđa ocjene? Senko i suradnici (2008) navode indirektni efekt ovladavanja na ocjene (interesom za gradivo, dubinskim procesiranjem), a taj indirektni efekt ima uglavnom slabiji efekt nego direktni efekt na ocjene (koji je više vezan uz ciljeve na izvedbu). Dakle, dubinsko procesiranje, kojim bi ovladavanje trebalo imati efekt na ocjene, nema efekt na ocjene. Ako pogledamo tablicu korelacija (Tablica 1.), možemo uočiti da je povezanost između dubinskog procesiranja i ocjena značajna, ali ipak dosta niska $r$ $=.25$, tako da se uključivanjem drugih varijabli u model efekt dubinskog procesiranja na ocjene izgubio. Ovakvi se nalazi mogu objasniti činjenicom da se znanje često ispituje zadacima višestrukog izbora koji uglavnom ispituju površinsko učenje materijala, a ne dublje razumijevanje i kritički pristup sadržaju (Senko i sur., 2008). Također, učenici koji imaju dubinski pristup učenju često pokazuju zanimanje za određenu temu u okviru gradiva, koju onda produbljuju do detalja, a zanemare ostale dijelove gradiva, ili ta tema nije od posebnog interesa nastavniku, pa možda i nije zastupljena $u$ ispitivanju. No, očekivali smo da će na ocjene iz fizike dubinsko 
procesiranje ipak imati učinak jer se znanje često ispituje problemskim zadacima, a ne zadacima višestrukog izbora. Međutim, većina je učenika sklona uvrštavanju brojeva u formule, bez razumijevanja odnosa među korištenim simbolima. Greeno (1987) navodi da je za rješavanje rutinskih zadataka potrebno proceduralno znanje koje podrazumijeva korištenje specifične operacije za postizanje cilja. Zadaci koji nisu rutinski (Greeno, 1987) zahtijevaju konceptualno (funkcionalno) znanje, koje podrazumijeva nalaženje novih funkcionalnih veza među pojmovima. Iz toga možemo zaključiti da je unatoč konceptualnim poteškoćama moguće riješiti velik broj rutinskih kvantitativnih zadataka iz područja prirodnih znanosti. Često se događa da učenici koji imaju dobre ocjene iz prirodnih predmeta jako dobro nauče koju formulu koristiti za pojedinu vrstu zadataka bez razumijevanja zašto je baš ta formula odgovarajuća, što nam može poslužiti kao objašnjenje zašto u ovom istraživanju nije dobiven značajan efekt dubinskog procesiranja na ocjene iz fizike.

Ovo istraživanje ima svoje nedostatke i ograničenja. Korišteni su upitnici samoprocjene, čiji je nedostatak upitna sposobnost sudionika da procjeni svoja ponašanja, mišljenja i čuvstva, problem referentne točke koji sudionik uzima pri procjeni i davanje socijalno poželjnih odgovora. Također, kada govorimo o mjerama strategija učenja, u istraživanju koje su proveli Cromley i Azevedo (2006) upitnici samoprocjene, kojima su mjerene strategije učenja, nisu korelirali s drugim mjerama strategija učenja ni s mjerama razumijevanja pročitanog teksta. Korištena je mjera uspjeha u fizici ocjena na kraju prethodnog razreda, pa bi bilo korisno (za buduća istraživanja) ponovno testirati model u kojem bi kriterij bio ocjena na kraju razreda koji su učenici trenutno pohađali. U ovom istraživanju dobivena je dosta niska pouzdanost skale usmjerenost na izvedbu putem izbjegavanja $(\alpha=.59)$ u Upitniku ciljeva postignuća. Smith, Duda, Allen i Hall (2002) naglašavaju općenito nešto nižu pouzdanost ove skale u različitim upitnicima u odnosu na ostale ciljeve postignuća. Smith i sur. (2002) su uspoređivali tri mjerna instrumenta ciljeva postignuća, a skala cilja izvedbe izbjegavanjem autora Elliot i Church (1997) također je pokazala nešto nižu pouzdanost $(\alpha=.65)$.

Nadalje, uzorak čine 208 učenika isključivo općega gimnazijskog usmjerenja. U istraživanje nije uzeto u obzir korištenje multiplih ciljeva. Naime, neka istraživanja (npr. Barron i Harackiewicz, 2001) pokazuju da upravo istovremeno korištenje usmjerenosti na ovladavanje i izvedbu uključivanjem ima najsnažniji efekt na pozitivne obrazovne ishode. Rezultati istraživanja temelje se na korelacijama. Rezultati korelacijskih istraživanja govore u kakvoj su vezi ispitivane varijable, ali nam ne kazuju ništa o uzročnosti te veze (Vizek Vidović, Rijavec, Vlahović-Štetić i Miljković, 2003). U svrhu ispitivanja odnosa među varijablama korištena je analiza traga u okviru strukturalnog modeliranja. Jedan je od nedostataka analize traga pretpostavka da su odnosi među varijablama jednosmjerni, odnosno, ako pretpostavimo da ciljevi postignuća imaju efekt na strategije učenja, ne možemo pretpostaviti i da strategije učenja te ocjene imaju efekt na ciljeve postignuća. Koncept ciljeva postignuća razvijen je u okviru teorija samoregulacije. Iz socijalno- 
kognitivne perspektive samoregulacijske funkcije uključuju samogeneriranje misli, osjećaja i ponašanja koja su planirana i ciklički prilagođena, te se baziraju na povratnoj informaciji u vidu izvedbe, radi postizanja ciljeva koje si je osoba postavila (Cleary, Platten i Nelson, 2007). Ciklus samoregulacije uključuje tri faze: faza prije, za vrijeme i nakon izvedbe. Faze su međuovisne, pa će o postavljenju ciljeva ovisiti koje će strategije osoba primijeniti i kako će na kraju sebe ocijeniti. Vrlo je važno na koji će način osoba izvoditi zaključke o uspjehu i čemu će pripisati uzrok vlastita uspjeha/neuspjeha jer će to utjecati na daljnje postavljanje ciljeva i ponašanje osobe u sličnim situacijama. Dakle, moguće da su odnosi među varijablama u ovom istraživanju dvosmjerni, a ne jednosmjerni, kako je pretpostavljeno modelom.

Ipak, unatoč navedenim nedostatcima ovo istraživanje upućuje na moguće nedostatke obrazovnog sustava (kao što je nepostojanje značajnog efekta dubinskoga kognitivnog procesiranja na ocjene iz fizike) te možemo zaključiti da postoji potreba daljnjeg istraživanja u ovom području. Rezultati istraživanja naglašavaju potrebu za usmjeravanjem učenika na učenje radi stjecanja znanja i kompetencija te potrebu za poticanjem metakognitivnih strategija. Ujedno, preporučljivo je poticanje strategija dubinskog procesiranja uz korištenje zadataka za ispitivanje znanja koji će ispitivati dubinsko procesiranje znanja, a ne učenje napamet i rutinsko uvrštavanje podataka u formule.

\section{Literatura}

Ames, C. (1992). Classrooms: Goals, structure, and student motivation. Journal of Educational Psychology, 84, 261-271.

Baron, R. M. i Kenny, D. A. (1986). The moderator-mediator variable distinctionin social psychological research: Conceptual, strategic, and statistical considerations. Journal of Personality and Social Psychology, 51, 1173-1182.

Barron, K. E. i Harackiewicz, J. M. (2001). Achievementgoals and optimal motivation: Testing multiple goal model. Journal of Personality and Social Psychology, 80(5), 706722 .

Barzegar, M. (2012). The relationshi between goal orientation and academic achievement the mediation role of self regulated learning strategies- $A$ analysis. Paper presented at International Conference on Management, Humanity and Economics, Phuket, Thailand.

Biggs, J. B. (1985). The role of metalearning in study processes. British Journal of Educational Psychology, 55, 185-212.

Cavallo, A. M. L., Rozman, M., Blickenstaff, J. i Walker N. (2003). Students' learning approaches, reasoning abilities, motivational goals, and epistemological beliefs in differing college science cours-es. Journal of College Science Teaching, 33(3), 18-23. 
Cleary, J. T., Platten, P. i Nelson, A. (2007). Effectiveness of self-regulation empowerment program with urban high school students. Journal of Advanced Academics, 20(1), 70107.

Coutinho, S. A. i Neuman, G. (2008). A model of metacognition, achievement goal orientation, learning style and self-efficacy. Learning Environments Research, 11, 131151.

Cromley, J. G. i Azevedo, R. (2006). Self-report of reading comprehension strategies: What are we measuring? Metacognition Learning, 1, 229-247.

Diseth, A. (2011). Self-efficacy, goal orientations and learning strategies as mediators between preceding and subsequent academic achievement. Learning and Individual Differences, 21(2), 191-195.

Diseth, A. i Martinsen, Ø. (2003). Approaches to learning, cognitive style, and motives as predictors of academic achievement. Educational Psychology, 23, 195-207.

Elliot, A. J. i Church, M. A. (1997). A hierarchical model of approach and avoidance achievement motivation. Journal of Educational Psychology, 72, 218-232.

Elliot, A. J. i McGregor, H. A. (2001). A 2 x 2 achievement goal framework. Journal of Personality and Social Psychology, 80(3), 501-519.

Fennolar, P., Román, S. i Cuestas, P. J. (2007). University student's academic performance: An integrative conceptual framework and empirical analysis. British Journal of Educational Psychology, 77, 873-891.

Finney, S. J., Pieper, S. L. i Barron, K. E. (2004). Examining the psychometric properties of theachievement goal questionnairein a general academic context. Educational and Psychological Measurement, 64, 365-382.

Georghiades, P. (2000). Beyond conceptual change learning in science education: Focusing on transfer, durability and metacognition. Educational Research, 42, 119-139.

Gilman, R. i Anderman, E. M. (2006). The relationship between relative levels motivation and intrapersonal, interpersonal, andacademic functioning among older adolescents. Journal of School Psychology, 44, 375-391.

Gottfried, A. E. (1985). Academic intrinsic motivation in elementary and junior high school students. Journal of Educational Psychology, 77, 631-645.

Gottfried, A. E. (1990). Academic intrinsic motivation in young elementary school children. Journal of Educational Psychology, 82, 525-538.

Greeno, J. G. (1987). Generative processes in representations of problems. Berkely: University of California.

Harackiewicz, J. M., Barron, K. E., Tauer, J. M., Carter, S. M. i Elliot, A. J. (2000). Short term and long-term consequences of achievement goals: Predicting interest and performance over time. Journal of Educational Psychology, 92, 316-330. 
Hulleman, C. S., Schrager, S. M., Bodmann, S. M. i Harackiewicz, J. M. (2010). A metaanalytic review of achievement goal measures: Different labels for the same constructs or different constructs with similar labels? Psychological Bulletin, 136(3), 422-449.

Jakšić, M. i Vizek Vidović, V. (2008) Ciljevi postignuća, percepcija kompetentnosti, spol i strategije učenja u općem akademskom kontekstu. Suvremena psihologija, 11, 7-24.

Kaplan, A. i Maehr, M. L. (2007). The contributions and prospects of goal orientation theory. Educational Psychology Review, 19(2), 141-184.

Kipins, M. i Hofstein, A. (2007). The inquiry laboratory as a source for development of metacognitive skills. Internation Journal of Science and Mathematics Education, 6, 601-627.

Lin, Y., McKeachie, W. J. i Kim, Y. C. (2003). College student intrinsic and/or extrinsic motivation and learning. Learning and Individual Differences, 13, 251-258.

Lleras, C. (2005). Path analysis. Encyclopedia of Social Measurement, 3, 25-30.

Lončarić, D. (2014). Motivacija i strategije samoregulacije učenja: Teorija, mjerenje $i$ primjena. Rijeka: Učiteljski fakultet u Rijeci.

Marušić, I. (2006). Nastavni programi iz perspektive učenika. U: B. Baranović (Ur.), Nacionalni kurikulum za obvezno obrazovanje u Hrvatskoj - različite perspektive (str. 175-213). Zagreb: Institut za društvena istraživanja.

Marton, F. i Saljo, R. (1976). On qualitative differences in learning - 1: Outcome and process. British Journal of Educational Psychology, 46, 4-11.

McDermott, P. A., Mordell, M. i Stoltzfus, J. C. (2001). The organization of student performance in American schools: Discipline, motivation, verbal, learning, nonverbal learning. Journal of Educational Psychology, 93, 65-76.

McGeown, S. P., Putwain, D., Simpson E. G., Boffey, E., Markham, J. i Vince, A. (2014). Predictors of adolescents' academic motivation: Personality, self-efficacy and adolescents' characteristics. Learning and Individual Differences, 32, 278-286.

Mirzaei, F., Phang, F. A., Sulaiman, S., Kashefi, H. i Ismail, Z. (2012). Mastery goals, performance goals, students' beliefs and academic success: Metacognition as a mediator. Procedia - Social and Behavioral Sciences, 46, 3603-3608.

Moller, A. C. i Elliot, A. J. (2006). The 2 x 2 achievement goal framework. The overview of empirical research. U: A.V. Mitel (Ur.), Focus on educational psychology (str. 307326). Hauppauge, NY: Nva Science Publishers, Inc.

Payne, S. C., Youngcourt, S. S. i Beaubien, J. M. (2007). A meta-analytic examination of the goal orientation nomological net. The Journal of Applied Psychology, 92(1), 128-150.

Pintrich, P. R. i De Groot, E. V. (1990). Motivational and self-regulated learning components of classroom academic performance. Journal of Educational Psychology, 82(1), 33-40.

Radosevich, D. J., Vaidyanathan, V. T., Yeo, S. i Radosevich, D. M. (2004). Relating goal orientation to self-regulatory processes: A longitudinal field test. Contemporary Educational Psychology, 29(3), 207-229. 
Rončević Zubković, B. i Kolić-Vehovec, S. (2014). Perceptions of contextual achievement goals: Contribution to high-school students' achievement goal orientation, strategy use andacademic achievement. Studia Psychologica, 56 (2), 137-153.

Rovan, D., Pavlin-Bernardić, N. i Vlahović-Štetić, V. (2013). Struktura motivacijskih uvjerenja u matematici i njihova povezanost s obrazovnim ishodima. Društvena istraživanja, 22(3), 475-495.

Senko, C., Durik, A. M. i Harackiewicz, J. M. (2008). Historical perspectives and new directions in achievement goal theory: Understanding the effects of mastery and performance-approach goals. U: J. Y Shah i W. Gardner (Ur.), Handbook of motivation science (str. 100-114). New York: Guilford.

Smith, M., Duda, J., Allen, J. i Hall, H. (2002). Contemporary measures of approach and avoidance goal orientations: Similarities and differences. British Journal of Educational Psychology, 72, 155- 190.

Sorić, I. (2014). Samoregulacija učenja. Jastrebarsko: Naklada Slap.

Utman, C. H. (1997). Performance effects of motivational state: A meta-analysis. Personality and Social Psychology Review, 1, 170-182.

Vizek Vidović, V., Rijavec, M., Vlahović-Štetić, V. i Miljković, D. (2003). Psihologija obrazovanja. Zagreb: IEP-VERN.

Vrdoljak, G., Kristek, M., Jakopec, A. i Zarevski, P. (2014). Provjera modela predviđanja akademskog postignuća studenata: Uloga proaktivnosti i pristupa učenju. Suvremena psihologija, 2, 123-134.

\title{
Relations between Achievement Goals, Learning Strategies and Grades in High School Physics Class
}

\begin{abstract}
The aim of this paper was to examine relations between achievement goals, learning strategies and grades in high school physics class. Achievement goals represent an important motivational construct that has been developed within the theories of the self-regulatory learning and are connected to various educational outcomes, for instance, learning strategies and grades. The study was conducted on 208 second- and third-grade grammar school students. In order to examine the above-mentioned variables, the study used: Achievement Goal Questionnaire (Elliot \& McGregor, 2001) which contains 12 items and measures four achievement goals: mastery approach, mastery avoidance, performance approach, and performance avoidance; Learning Strategies Scale (Lončarić, 2014) which contains 39 items and measures three learning strategy subscales: cycles of metacognitive control, deep cognitive processing, and surface cognitive processing. Class success criterion was previous year's physics grade. The relations between variables were verified by path analysis method. The study greatly confirmed anticipated relations (based on previous research). The achievement goals with approach tendencies have significantly positive effect on preferable educational outcomes. Achievement goals with avoidance tendencies are positively connected to surface processing. The results also confirmed the mediating effect of learning strategies in relation
\end{abstract}


to mastery-approach goals and physics grades. This study emphasizes the necessity to direct students to learn in order to acquire the knowledge and competencies, and encourage the use of metacognitive strategies. This study, also, indicates some potential problems within the educational system (for instance, the absence of significant effect of the deep cognitive processing on the physics grades) which suggest the need for further research in this area.

Keywords: achievement goals, learning strategies, physics, high school

\section{Relación entre las metas de logro, las estrategias del aprendizaje y las notas en la enseñanza de física en la escuela media}

\section{Resumen}

El objetivo de este trabajo fue verificar la relación entre las metas de logro, las estrategias del aprendizaje y las notas en la enseñanza de física en la escuela media. Las metas de logro representan un constructo de motivación importante que se desarrolló en el marco de teorías del aprendizaje autorregulado y se asocian con diferentes resultados educativos como por ejemplo estrategias del aprendizaje y notas. La investigación se llevó a cabo con 208 participantes, alumnos de la segunda y la tercera clase del instituto general de educación secundaria. Con el fin de verificar las metas de logro y estrategias del aprendizaje se utilizó el Cuestionario de Metas de Logro (Elliot y McGregor, 2001) que consta de 12 partículas y mide cuatro metas de logro: dominación por inclusión, dominación por evitación, realización por inclusión y realización por evitación. También fue utilizada la Escala de Estrategias del Aprendizaje (Loncaric, 2014) que consta de 39 partículas y mide tres subescalas de estrategias del aprendizaje: ciclo del control metacognitivo, procesamiento cognitivo profundo y procesamiento cognitivo superficial. Como medida de éxito en física se tomó la nota al final de la clase anterior. Las supuestas relaciones entre variables se verificaron a través del método de análisis del camino dentro del modelado estructural. La investigación demostró que las metas de logro predicen significativamente los resultados educativos en la enseñanza de física: estrategias del aprendizaje y notas. También demostró que las supuestas relaciones (basadas en las investigaciones previas) se confirmaron en gran medida. Las metas de logro con tendencia a inclusión tienen un efecto positivo significativo sobre resultados educativos deseables. Las metas de logro con tendencia a evitación tienen una relación positiva con el procesamiento superficial. Los resultados confirmaron también el efecto mediador que tienen las estrategias del aprendizaje en relación entre las metas de logro para la dominación por inclusión y notas de física. Esta investigación acentúa la necesidad de guiar a los alumnos para que estudien con el fin de adquirir conocimiento y competencias. También acentúa la necesidad de estimular para usar las estrategias metacognitivas. Además, esta investigación indica posibles defectos del sistema educativo (como, por ejemplo, la falta de efecto significativo del procesamiento cognitivo profundo sobre las notas de física), lo que indica la necesidad de futuras investigaciones en este campo.

Palabras clave: metas de logro, estrategias del aprendizaje, física, alumnos de la secundaria

Primljeno: 11.04.2016. 